\title{
AKTIVITAS ANTIOKSIDAN EKSTRAK BIJI DUWET (Syzygium cumini Linn.) PADA PEROKSIDASI LIPIDA SECARA IN VITRO
}

\author{
Antioxidant Activity of Duwet Seed (Syzygium cumini Linn.) Extract on Lipid Peroxidation Models in Vitro \\ Rohadi', Sri Raharjo², lip Izul Falah', Umar Santoso²

\begin{abstract}
${ }^{2}$ FakultasTeknologi Pertanian, Universitas Gadjah Mada, Jl. Flora No. 1, Bulaksumur, Yogyakarta 55281
${ }^{3}$ Fakultas Matematika dan Ilmu Pengetahuan Alam, Universitas Gadjah Mada,

Jl. Sekip Utara Kotak Pos 21, Bulaksumur, Yogyakarta 55281

Email: umar_santoso@yahoo.com
\end{abstract} \\ ${ }^{1}$ Fakultas Teknologi Pertanian, Universitas Semarang (USM), Jl. Arteri Soekarno-Hatta Semarang 50196
}

\begin{abstract}
ABSTRAK
Tanaman duwet (Syzygium cumini Linn.) pada semua kompartemennya dimanfaatkan masyarakat untuk pengobatan suatu penyakit. Ekstrak bijinya dimanfaatkan untuk penurun gula darah. Bijinya merupakan bagian tanaman yang kaya senyawa polifenol. Fraksi kaya senyawa fenolik dipreparasi dengan mengekstraksi biji duwet varietas "Genthong", dengan tiga jenis ekstraktan; etil acetat 85\%, metanol 50\% dan etanol 50\%. Ekstrak biji duwet (EBD) yang diperoleh dianalisis kelompok senyawa fenolik dan aktivitas antioksidan menggunakan metode uji penangkapan radikal DPPH (2,2-diphenil 1-picrylhydrazyl), uji reduksi ion Feri (ferric reduction antioxidant power-FRAP) dan uji penghambatan peroksidasi asam lemak linoleat. Tujuan penelitian adalah memilih satu dari tiga ekstraktan yang menghasilkaan ekstrak, dengan yield dan kadar senyawa polifenolik terbesar serta sifat antioksidatif terkuat. Yield dengan ekstraktan Met-OH-50\%, sebesar 16,29\% (db), senyawa fenoliknya sebesar 45,99 $\pm 0,25$ g-GAE/100 g-EBD; 2,28 $\pm 0,07$ g-QE/100

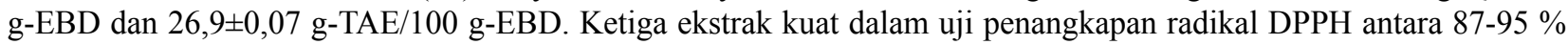
$\left(100 \mu \mathrm{g}-\mathrm{mL}^{-1}\right)$ dan uji reduksi ion Feri $\left(\mathrm{Fe}^{3+}\right)$, moderat pada uji penghambatan peroksidasi lipid, 49-52 \% pada $400 \mu \mathrm{g}-$ $\mathrm{mL}^{-1}$.
\end{abstract}

Kata kunci: Biji duwet (Syzygium cumini Linn.), antioksidan, ekstraksi

\begin{abstract}
All parts of Syzygium cumini Linn. (duwet) were widely used for medicinal plant in the treatment of various deseases. The seed extract was used to lower blood glucose. Cumini's seed had higher phenolic fractions than others. It were prepared by extracted of duwet seed "Genthong" varieties, using various extractants such as $85 \%$ ethyl acetate, 50\% methanol and 50\% ethanol. Duwet seed extract collected then was determined of phenolics compound and antioxidant activity assayed by measuring 2,2-diphenyl-1-picrylhydrazylradical (DPPH) scavenging activity, reducing Ferric ion $\left(\mathrm{Fe}^{3+}\right)$ power and inhibition of linoleic acid oxidation. The objective was to select one of the extractant which gave highest yield and polyphenolic content and its stronger antioxidant activity. Extractant 50\% methanol gave highest the extract yields was $16.29 \%$ (db.) and phenolics compounds of extract was composed: total phenolic $45.99 \pm 0.25$ g-GAE/100 g-extract; total flavonoid $2.28 \pm 0.07 \mathrm{~g}$-QE/100 g-extract and total tannin 26.9 $\pm 0.07 \mathrm{~g}$-TAE/100 g-extract. All of extract exhibited strong on behalf of RSA-DPPH assay $87-95 \%\left(100 \mu \mathrm{g}-\mathrm{mL}^{-1}\right)$ and reducing power, nevertheless in inhibition of linoleic acid oxidation was moderate $49-55 \%\left(400 \mu \mathrm{g}-\mathrm{mL}^{-1}\right)$.
\end{abstract}

Keywords: Syzygium cumini Linn, seed, antioxidant, extraction

\section{PENDAHULUAN}

Oksidasi merupakan penyebab utama kerusakan lipid dan pangan berminyak. Oksidasi lipid berlangsung dalam tiga mekanisme: (1) oksidasi spontan (auto oxidation) oleh oksigen udara, (2) oksidasi yang diinisiasi cahaya (photooxidation), dan (3) oksidasi oleh panas (thermal oxidation). Lipid (trigliserida) dimungkinkan tersusun baik oleh asam lemak jenuh (saturated fatty acids) dan asam lemak tidak jenuh (unsaturated fatty acids) yang rentan rusak oleh 
oksidasi, sehingga dihasilkan flavor menyimpang (off-flavor) selama proses pengolahan dan penyimpanan. Asam lemak jenuh adalah materi yang kekurangan elektron pada atom oksigen $\left(\mathrm{O}_{2}\right)$ pada sisi ikatan karbonil $(\mathrm{C}=\mathrm{O})$, sementara asam lemak tidak jenuh, kekurangan elektron pada sisi ikatan rangkapnya $(\mathrm{C}=\mathrm{C})$. Kondisi ini menyebabkan asam lemak rentan atas serangan elektron dari radikal bebas melalui peristiwa oksidasi (Brewer, 2011). Pada sisi lain atom karbon (C) dari asam lemak tidak jenuh yang berada diantara dua ikatan rangkap (allelic) berpotensi mengabstraksi atom $\mathrm{H}^{\circ}$ hingga terbentuk radikal alkil diena terkonjugasi ( $\left.\mathrm{R}^{*}\right)$, yang selanjutnya R'teroksidasi menjadi peroksil radikal (ROO') dan hidroperoksida $(\mathrm{ROOH})$ dalam fase propagasi. Oksidasi bersifat termodinamika dan dipicu oleh senyawa radikal (Shahidi dan Zhong, 2005; Brewer, 2011).

Penambahan antioksidan sintetis pada lipid dan pangan berminyak adalah metode yang umum dan efektif untuk penghambatan kerusakan oksidatif. Namun demikian, penambahan antioksidan sintetis seperti butylated hydroxyanisole (BHA), butylated hydroxytoluene (BHT), propyl gallate ( $\mathrm{PG})$, dan tert-butylhydroquinone (TBHQ) pada pangan belum sepenuhnya diterima konsumen, karena bersifat toksik dan karsinogenik (Madavi dan Salunke, 1995; Buxiang dan Fukuhara, 1997; Baydar dkk., 2007; Vayupharp dan Laksanalamai, 2012). Antioksidan alami diyakini sebagai antioksidan alternatif yang aman.

Tanaman duwet (Syzygium cumini Linn.) nama lainnya Syzygium jambolanum Lam., atau Eugenia cumini Druce, pada semua kompartemennya dimanfaatkan masyarakat untuk pengobatan tradisional (Sultana dkk., 2007; Ayyanar dan Babu, 2012; Ahsan dkk., 2012). Biji duwet merupakan limbah, berpotensi sebagai antioksidan alami pada pangan sebab kaya senyawa polifenolik (Vasi dan Austin, 2009; Peixoto dan Freitas, 2012; Saha dkk., 2013; Rydlewski dkk., 2013). Senyawa polifenolik menunjukkan kemampuan antioksidatifnya melalui tiga mekanisme: (1) scavenging radical species, (2) penghambatan enzimatis atau pengkelat logam yang terlibat pada pembentukan radikal bebas serta (3) perlindungan atas oksidan (Dai dan Mumper, 2010).

Rydleski dkk. (2013) menyatakan biji duwet sumber senyawa fenolik. Ekstrak metanoliknya mengandung senyawa organik setara 411,02 mg-GAEq/liter, kulit buahnya setara 227,83 mg-GAE/liter, dan pada daging buah (flash) setara 225,56 mg-GAE/liter. Ditambahkan nilai penghambatan $50 \%$ radikal DPPH $\left(\mathrm{IC}_{50}\right)$ ekstrak biji duwet sebesar 15,47 $\mu \mathrm{gml}^{-1}$. Vasi dan Austin (2009) menyebutkan yield ekstrak biji duwet (bebas etanol 50\%) sebesar 12,96\%, dan mengandung senyawa fenolik 27,37 $\pm 0,18 \mathrm{mg}$-GAE/g-ekstrak dan flavonoid 14,7 $\pm 0,0,09$ mg-QE/g-ekstrak, serta memiliki kapasitas antioksidan maksimal $98,92 \%$ (RSA-ABTS) dan 52,46\%

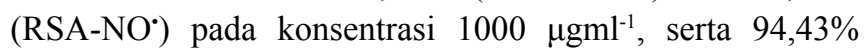

(uji FRAP) dan 53,47\% (RSA-DPPH) pada konsentrasi 800 $\mu \mathrm{gml}^{-1}$. Saha dkk. (2013) menyatakan fenolik total dalam sari buah, pulp dan biji duwet berturut-turut sebesar 6.900, 20.700 dan $21.000 \mathrm{mg}-\mathrm{TAE} / \mathrm{kg}$ (pelarut metanol).

Di Indonesia berkembang tiga varietas duwet yakni "duwet genthong", "kerikil" dan "duwet puteh". Varietas "duwet genthong", lebih banyak tumbuh secara sporadis di Jawa Tengah dan buahnya dimanfaatkan sebagai buah meja. Musim panen duwet antara bulan Nopember hingga Desember, dengan produktivitas $50-80 \mathrm{~kg}$. buah/musimpohon.

Tujuan penelitian adalah memilih ekstraktan yang sesuai dari tiga jenis: etil asetat $85 \%(\mathrm{v} / \mathrm{v})$, etanol $50 \%(\mathrm{v} / \mathrm{v})$ dan metanol $50 \%(\mathrm{v} / \mathrm{v})$, dengan parameter: yield, kelompok senyawa fenolik (fenolik total, flavonoid total, dan tannin total) dan uji aktivitas antioksidan yang meliputi uji penangkapan radikal DPPH (radical scavenging activity 2,2-dipheny 1-1picrylhydrazyl), uji reduksi ion Ferik, $\mathrm{Fe}^{3+}($ ferric reduction antioxidant power- FRAP) dan uji penghambatan peroksidasi asam lemak linoleat atas ekstrak yang diperoleh. Ketiga jenis ekstraktan tersebut telah direkomendasikan oleh beberapa peneliti sebelumya sebagai ekstraktan yang efektif untuk ekstraksi senyawa polifenolik dari biji duwet (Vasi dan Austin, 2009) pada biji anggur (Vayupharp dan Laksanalamai, 2012).

\section{METODE PENELITIAN}

\section{Bahan dan Alat Penelitian}

Bahan penelitian berupa bubuk kering biji duwet (Syzygium cumini Linn.) varietas "Genthong", kadar air $\leq$ $14 \%$, lolos ayakan $\geq 80$ mesh, diperoleh dari penggilingan (cutting mill) bagian kernel. Diperoleh dari buah duwet segar dan masak optimal (warna ungu-kehitaman) yang dipetik dari tanaman duwet milik warga di Jl. Cempedak, Lamper Kidul, Kota Semarang, Jawa Tengah, yang sudah teridentifikasi secara taksonomi (authenticating) di Laboratorium Taksonomi Tanaman, Fakultas Biologi, Universitas Gadjah Mada (UGM), Yogyakarta.

Bahan kimia meliputi etanol, metanol, ethyl acetat. Folin Ciocalteu reagent, gallic acid (Sigma Chemical Co. St. Louis USA), asam askorbat, tannic acid (Sigma), quercetin (Waco Pure Chemical Industry-Osaka Japan), butylated hydroxyanisole -BHA (Sigma Chemical Co.), aqueous $\mathrm{Na}_{2} \mathrm{CO}_{3}$, Tween-40, $\mathrm{HCl}$, buffer phospat $\mathrm{pH} 7$, Ferrous Chlorida $\left(\mathrm{FeCl}_{2}\right)$,Ferric Chloride $\left(\mathrm{FeCl}_{3}\right)$,amonium thiocyanat, $\mathrm{K}_{3} \mathrm{Fe}(\mathrm{CN})_{6}$, trychloroacetic acid (TCA),tungstophosporic acid 2,2-diphenyl-1-picryl hydroxyl radical (DPPH), dan asam lemak linoleat. Semua bahan kimia yang dipakai berkategori analisis (analytical grade) dan teknis. Peralatan meliputi pengering tipe kabinet (cabinet dryer), 
mesin penggiling (cutting mill), ayakan Tyler, a rotary vacuum evaporator (IKA-RV 10 basic), vortex, inkubator, water-bath shaker (Julabo SW 22), UV-Visible spectrophotometer (UV1601 Shimadzu) dan HPLC.

\section{Analisis Proksimat Daging Buah dan Tepung Biji Duwet (TBD)}

Analisis daging buah dan tepung biji duwet (TBD) meliputi: analisis kadar air secara termogravimetri menurut (AOAC, 2005), protein menurut (AOAC, 2005), lemak (AOAC, 2005), serat kasar (AOAC, 2005), abu (AOAC, 2005), jenis gula (sukrosa, glukosa, galaktosadan fruktosa) dengan HPLC dan kandungan mineral: $\mathrm{Ca}, \mathrm{Cu}, \mathrm{Fe}, \mathrm{Mg}, \mathrm{Na}, \mathrm{K}$ dan P dengan metode Atomic Absorption Spectroscopy-AAS (AOAC, 2005).

\section{Ekstraksi Biji Duwet}

TBD diesktrak dengan pelarut metanol/air, 50\% (v/v), etanol/air 50\%, (v/v), dan etil-acetat 85\% (v/v) menurut (Vasi dan Austin, 2009). Sebanyak 25 gram TBD diekstraksi berulang $(3 \mathrm{x})$ dengan pelarut yang sama pada rasio bahan: pelarut $(1: 10)$ secara maserasi 6 jam, suhu ruang $\left(28 \pm 2^{\circ} \mathrm{C}\right)$ dengan water-bath shaker (Julabo SW 22, 100 rpm). Ekstrak dipekatkan dengan a rotary vacuum evaporator, hingga diperoleh cairan kental (crude solid extract) dan dikering bekukan dengan freeze dryer (Virtis SP Scientific Sentry 2.0) dilanjutkan dengan penyemprotan dengan gas nitrogen sampai diperoleh ekstrak biji duwet bebas pelarut (EBD). Selanjutnya EBD disimpan pada suhu beku $\left(-20{ }^{\circ} \mathrm{C}\right)$ untuk pemakaian berikutnya. Tiap eksperimen dilakukan tiga kali ulangan.

\section{Analisis Senyawa dan Aktivitas Antioksidan}

EBD ditera yield (\%), senyawa fenolik dan flavonoid total menurut (Ebrahimzadeh dkk., 2008) dan peneraan tanin total menurut, (Palici dkk., 2005). Pada EBD dilakukan pula uji aktivitas antioksidan metode radical scavenging activityDPPH menurut Vasi dan Austin (2009), ferric reducing power (FRAP) menurut Vasi dan Austin (2009), linoleic acid peroxidation menurut (Jayaprakasha dkk., 2001). Data dianalisis secara statistik untuk dipilih ekstraktan yang menghasilkan yield, kelompok senyawa fenolik terbesar dan aktivitas antioksidan terkuat untuk dilakukan fraksinasi dan identifikasi jenis senyawa fenoliknya dan aplikasi sebagai antioksidan alami pada minyak ikan patin (Pangasius hypothalamus).

\section{Penentuan Kadar Senyawa Fenolik}

Kadar senyawa fenolik total EBD ditera secara spektrometri dengan metode pewarnaan Folin-Ciocalteu
Reagent (FCR) pada absorbansi $\lambda=765 \mathrm{~nm}$ dengan gallic acid sebagai standarnya menurut (Ebrahimzadeh dkk., 2008), dan dinyatakan sebagai (g GAE/100 g.EBD). Kadar senyawa flavonoid total ditera secara spektrometri pada absorbansi $\lambda=415 \mathrm{~nm}$ dengan quercetine sebagai standarnya menurut (Ebrahimzadeh dkk., 2008; Vasi dan Austin, 2009), dinyatakan dalam persen (g.QE/100g.EBD). Kadar senyawa tanin total ditera secara spektrometri pada absorbansi $\lambda=725$ $\mathrm{nm}$ dengan tannic acid sebagai standarmenurut (Palici dkk., 2005) dinyatakan dalam persen (\%) sebagai g. TAE/100 g. EBD.

\section{Pengukuran Radical Scavenging Activity (RSA)-DPPH}

Pengukuran radical scavenging activity (RSA)-DPPH EBD dikerjakan menurut prosedur Vasi dan Austin (2009). Secara ringkas sebanyak $0.5 \mathrm{~mL}$ EBD berbagai konsentrasi $(10,25,50,75,100,150$ dan $200 \mathrm{ppm})$ dalam etanol 50\%+0,5 $\mathrm{mL} 2$,2-diphenyl-1-picryl hydroxyl radical (DPPH)-100 $\mu \mathrm{M}$, diinkubasi di dalam ruang gelap pada suhu ruang $\left(37 \pm 2{ }^{\circ} \mathrm{C}\right)$ selama 30 menit. Scavenging activityradikal DPPH diamati dengan membaca absorbansinya pada $\lambda=517$ nmUV-Vis spectrometer (UV-1601 Shimadzu). Eksperimen dilakukan dengan tiga kali ulangan. Vitamin C, BHA dan quercetin dipakai sebagai pembanding. Aktivitas penangkapan radikal bebas DPPH dapat dihitung dengan persamaan Vasi dan Austin (2009):

$$
\begin{aligned}
\text { RSA-DPPH }(\%)= & 1-[\text { Nilai } \Delta \text { absorbansi sampel/Nilai } \\
& \Delta \text { absorbansi kontrol }] \times 100 \%
\end{aligned}
$$

\section{Pengukuran Daya Reduksi Ion Feri $\left(\mathrm{Fe}^{+3}\right)$}

Kemampuan mereduksi ion ferik, $\mathrm{Fe}^{+3}$, ferric reducing antioxidant power (FRAP) dipakai sebagai indikator aktivitas transfer elektron senyawa fenolik Vasi dan Austin (2009). Ringkasnya sebanyak 2,5 ml EBD berbagai konsentrasi (50,100,200, 400,800 dan $1000 \mathrm{ppm})$ dalam etanol ditambah 2,5 mL buffer pospat 0,2 M, pH =6,6 ditambahkan 2,5 mL $\mathrm{K}_{3} \mathrm{Fe}(\mathrm{CN})_{6}$ sebesar $1 \%$. Campuran tersebut diinkubasi pada suhu $50^{\circ} \mathrm{C}$ selama 20 menit, selanjutnya ditambahkan 2,5 $\mathrm{mL}$ trichloroacetic acid ( TCA) $10 \%$ untuk menghentikan rekasi. Campuran selanjutnya dilakukan sentrifugasi (vortex) pada $3.000 \mathrm{rpm}$ selama 10 menit. Dari campuran diambil 2,5 $\mathrm{mL}$ supernatan, ditambahkan padanya $2,5 \mathrm{~mL}$ aquades dan $0,5 \mathrm{~mL}$ feri klorida $\left(\mathrm{FeCl}_{3}\right)$ 0,1\%. Kemampuan mereduksi sampel ditera dengan pengukuran absorbansi pada $\lambda=700 \mathrm{~nm}$. Peningkatan absorbansi sebagai indikator pengkatan ndaya mereduksi. Sebagai pembanding daya mereduksi sampel digunakan vitamin $\mathrm{C}$. 


\section{Aktivitas Antioksidan dengan Metode Peroksidasi Asam Linoleat}

Untuk mengetahui aktivitas penghambatan oksidasi dilakukan dengan metode peroksidasi asam lemak linoleat menurut Jayaprakasha dkk. (2001). Secara ringkas diawali dengan pembuatan emulsi asam lemak linoleat. Sebanyak 0,28 gram asam linoleat, 0,28 gram Tween-40 dan 50 $\mathrm{mL}$ buffer phosphate $(0,2 \mathrm{M}-\mathrm{pH}=7,0)$ dicampur dan dihomogenisasi. Sebanyak 0,5 mL larutan EBD (Met-OH $60 \%$ ) dalam berbagai konsentrasi (50-800 ppm), dicampur dengan 2,50 mL emulsi asam linoleat dan 2,5 $\mathrm{mL}$ buffer phosphate $(0,2 \mathrm{M} / \mathrm{pH}=7,0)$ dan diinkubasi pada suhu $37^{\circ} \mathrm{C}$, selama 120 jam (5 hari). Sampel kontrol disiapkan seperti diuraian di atas, tanpa EBD. Sebanyak 0,1 mL (diambil dari cairan yang diinkubasi) pada interval 24 jam dicampur dengan $5 \mathrm{~mL}$ etanol 75\%, 0,1 $\mathrm{mL}$ ammonium thiocyanate $30 \%$, dan $0,1 \mathrm{~mL}$ larutan $20 \mathrm{mM}$ Ferrous Chloride $\left(\mathrm{FeCl}_{2}\right)$ dalam 3,5\% $\mathrm{HCl}$. Campuran tersebut diinkubasi dalam suhu ruang selama 3 menit. Pada campuran akan terbentuk warna merah bata dan tera absorbansinya pada $\lambda=500 \mathrm{~nm}$. BHA dan quercetin dipakai sebagai pembanding. Aktivitas antioksidan dapat dihitung dengan persamaan Jayaprakasha dkk. (2001):

Aktivitas antioksidan $=100-\left[\frac{(\text { Perubahan }}{(\text { Perubahan }} \frac{\text { nilai }}{\text { nilai }} \frac{\mathrm{OD}}{\mathrm{OD}} \frac{\text { sampel })}{\text { kontrol })}\right] \times 100$

\section{Analisis Data}

Data disajikan dalam format rata-rata \pm SD. Analisis statistik menggunakan one-way Anova dengan tingkat signifikansi $95 \%$ dan bila ada perbedaan nyata antarperlakuan dilanjutkan dengan uji Duncan's Multiple Range Test (DMRT) dengan program statistik SPSS 21 for Windows, SPSS Inc. Chicago, USA. Analisis regresi diterapkan untuk melihat korelasi antar variabel.

\section{HASIL DAN PEMBAHASAN}

\section{Sifat Fisikokimia Buah dan Biji Duwet}

Identifikasi sifat fisik dan kimia buah dan biji duwet (Syzygium cumini Linn.) varietas "Genthong", terlihat pada Tabel 1. Identifikasi sifat fisikokimia diperlukan untuk memberikan diskripsi duwet varietas "Genthong" lebih komprehensif. Adapun identifikasi sifat kimia biji duwet bertujuan untuk menyediakan data yang dimungkinkan korelatif dengan sifat antioksidatifnya.

Sifat fisikokimia buahnya sedikit berbeda dengan yang disampaikan (Baliga dkk., 2011; Swami dkk., 2012). Hal ini disebabkan perbedaan varietas duwet, usia petik dan lokasi tumbuhnya. Gula jenis fruktosa dan glukosa pada duwet "Genthong", cukup dominan dan sebaliknya sedikit sukrosa maupun galaktosa. Hal ini sesuai dengan yang dilaporkan Saha dkk. (2013) bahwa dua jenis gula fruktosa dan glukosa cukup dominan pada buah duwet. Jumlah vitamin $\mathrm{C}$ pada daging buahnya moderat, sementara mineral kalium (K), magnesium $(\mathrm{Mg})$, dan besi (Fe) jumlahnya cukup besar terutama pada biji duwet.

Tabel 1. Sifat fisikokimia duwet varietas "Genthong"

\begin{tabular}{|c|c|c|c|}
\hline Sifat fisik & Buah duwet & Referensi** & Biji duwet \\
\hline Bentuk & Oblong & Bulat-Oblong & Oblong \\
\hline Berat (g/buah) & $8,06 \pm 1.21$ & $4,8-1, .6$ & $1,67 \pm 0,31$ \\
\hline Panjang (cm) & $3,08 \pm 0,17$ & $2,22-4,51$ & $2,18 \pm 0,15$ \\
\hline Lebar $/ \varphi(\mathrm{cm})$ & $2,07 \pm 0,11$ & $1,66-3,04$ & $1,03 \pm 0,05$ \\
\hline Warna $\left(* \mathrm{~L} ; \mathrm{a}^{*} ; \mathrm{b} *\right)$ & 28,$85 ; 2,44 ;-0,33$ & Ungu-Hitam & 63,$92 ; 2,67 ; 9,88$ \\
\hline Sifat Kimia & Pulp & Pulp & TBD \\
\hline Air (\%) & $87,87 \pm 0,37$ & $85,9 \pm 1,4$ & $14,45 \pm 0,22$ \\
\hline Protein, $\mathrm{fk}=6,25(\%)$ & $1,3 \pm 0,24$ & $1,4 \pm 0,7$ & $5,67 \pm 0,08$ \\
\hline Lipid (\%) & $0,67 \pm 0,08$ & $0,6 \pm 0,2$ & $0,66 \pm 0,02$ \\
\hline Abu (\%) & $0,30 \pm 0,01$ & $<0,22 \pm 0,04$ & $3,82 \pm 0,04$ \\
\hline Karbohidrat Total (\%) & $10,98 \pm 0,15$ & $16,6 \pm 1,2$ & $75,4 \pm 15$ \\
\hline Serat Tidak Terlarut (\%) & $1,32 \pm 0,15$ & $0,6 \pm 0,06$ & $1,24 \pm 0,17$ \\
\hline Sukrosa (ppm) & 2.120 & 95.500 & $1.684,33$ \\
\hline Fruktosa (ppm) & 37.743 & 57.500 & 27.800 \\
\hline Galaktosa (ppm) & $<29,85$ & 52.500 & 22.400 \\
\hline Glukosa (ppm) & 33.394 & 20.000 & 761,06 \\
\hline Vitamin C (ppm) & $845,1 \pm 8.3$ & $30 \pm 6,9$ & $*$ \\
\hline $\mathrm{Mg}(\mathrm{ppm})$ & $145,1 \pm 1.0$ & $498 \pm 12$ & $2.161,5 \pm 16,6$ \\
\hline $\mathrm{Na}(\mathrm{ppm})$ & $33,2 \pm 6,9$ & $35 \pm 8$ & $115,2 \pm 2,45$ \\
\hline $\mathrm{Ca}(\mathrm{ppm})$ & $279,2 \pm 16.4$ & $215 \pm 15$ & $86.6 \pm 0.9$ \\
\hline $\mathrm{K}(\mathrm{ppm})$ & $1.459,1 \pm 211$ & $1.300 \pm 80$ & $8.812,8 \pm 60.8$ \\
\hline $\mathrm{P}(\mathrm{ppm})$ & $731.3 \pm 99.7$ & $185 \pm 28$ & $35,8 \pm 4,8$ \\
\hline $\mathrm{Fe}(\mathrm{ppm})$ & * & $1,5 \pm 0,1$ & $136,8 \pm 0,19$ \\
\hline $\mathrm{Cu}(\mathrm{ppm})$ & $*$ & $0,7 \pm 0,2$ & $5,0 \pm 0,28$ \\
\hline
\end{tabular}

Keterangan: $*=$ tidak dilakukan analisis/tidak ada data $* *=$ Baliga, dkk. (2011)

\section{Yield Ekstraksi Tepung Biji Duwet}

Nilai yield ekstraksi TBD dengan tiga ekstraktan masingmasing etil asetat 85\% (EtO-Ac), metanol 50\% (Met-OH) dan etanol 50\% (Et-OH) berturut-turut adalah 3,53 $\pm 0,72 \%$ (db), 16,29 $\pm 0,50$ dan 14,2 $\pm 0,56 \%$ (dry-basis) ditunjukkan pada Tabel 2. Tampak bahwa pengaruh ekstraktan atas rendemen yang diperoleh berbeda nyata $(P<0.05)$, ekstraktan metanol 50\% dihasilkan rendemen tertinggi. Sifat polaritas ekstraktan yang berbeda, berpengaruh atas pencapaian yield. Diketahui metanol 50\% adalah ekstraktan terpolar diantara ketiganya. Hasil serupa ditunjukkan oleh Sultana dkk. (2007) yang menggunakan pelarut metanol $80 \%$, etanol $80 \%$ dan aseton $80 \%$ untuk mengesktrak senyawa fenolik dari kulit kayu duwet (Syzygium cumini Linn.), yang mana yield yang dihasilkan oleh metanol $80 \%$ tertinggi, yakni beturut-turut $14,1 \pm 0,56 \%, 13,5 \pm 0,27$ dan 3,60 $\pm 0,11 \%$. Vasi dan Austin (2009) menyebutkan yield ekstrak biji duwet dengan pelarut etanol 50\% sebesar 12,96\%. Perbedaan nilai dengan hasil di atas dimungkinkan karena perbedaan varietas duwet yang digunakan. 
Tabel 2. Karakteristik EBD yang dihasilkan tiga jenis pelarut

\begin{tabular}{|c|c|c|c|c|c|c|c|}
\hline Ekstrak & $\begin{array}{l}\text { Yield } \\
(\%)\end{array}$ & $\begin{array}{c}\text { Fenolik total* } \\
\qquad(\%)\end{array}$ & $\begin{array}{l}\text { Flavonoid total } * * \\
\qquad(\%)\end{array}$ & $\begin{array}{c}\text { Tanin total } * * * \\
(\%)\end{array}$ & $\begin{array}{c}\text { RSA-DPPH } \\
(\%)\end{array}$ & $\begin{array}{l}\text { FRAP } \\
(\mathrm{OD})\end{array}$ & $\begin{array}{c}\text { Penghambatan } \\
\text { oksidasi (\%) }\end{array}$ \\
\hline EtO-Ac85 & $3,53 \pm 0,72 \mathrm{a}$ & $10,77 \pm 0,28 \mathrm{a}$ & $0,33 \pm 0,002 \mathrm{a}$ & $6,32 \pm 0,26 a$ & $87,85 a$ & $2,97 \mathrm{a}$ & $52,75 \mathrm{c}$ \\
\hline Et-OH50 & $14,2 \pm 0,56 b$ & $42,39 \pm 0,17 b$ & $2,28 \pm 0,06 \mathrm{~b}$ & $22,21 \pm 0,10 b$ & $90,59 b$ & $2,82 \mathrm{a}$ & $52,25 c$ \\
\hline Met-OH50 & $16,29 \pm 0,5 b$ & $45,99 \pm 0,25 c$ & $2,28 \pm 0,07 \mathrm{~b}$ & $26,90 \pm 0,07 \mathrm{c}$ & $91,90 \mathrm{~b}$ & $2,84 \mathrm{a}$ & $49,17 \mathrm{ab}$ \\
\hline
\end{tabular}

Keterangan: $* \quad=$ Fenolik total $(\mathrm{g}-\mathrm{GAE} / 100$ g-ekstrak)

$* * \quad=$ Flavonoid total $(\mathrm{g}-\mathrm{QE} / 100 \mathrm{~g}$-ekstrak)

$* * * \quad=$ Tanin total (g-TAE/100g-ekstrak)

RSA-DPPH (\%) pada 100 ppm, FRAP (OD) pada 400 ppm dan penghambatan lipoksidasi asam linoleat (\%) pada 400 ppm

Notasi huruf yang berbeda pada kolom yang sama menunjukkan adanya perbedaan nyata pada tingkat kepercayaan $95 \%(\mathrm{p}<0,05)$

\section{Kadar Senyawa Polifenolik}

Analisis kuantitatif komposisi senyawa polifenolik dari ekstrak biji duwet (EBD) yang diperoleh diekspresikan dengan tiga cara, yakni ekuivalensi asam galat (gallic acid equivalen-GAE) untuk fenolik total dengan kurva standar $\mathrm{y}=$ $7.144 \mathrm{x}-0.034, \mathrm{r}^{2}=0,986$, ekuivalensi kuersetin (quercetin equivalen- $Q E$ ) untuk flavonoid total dengan kurva standar $\mathrm{y}=$ $1.364 \mathrm{x}+0.006, \mathrm{r}^{2}=0,996$ dan ekuivalensi asam tanat (tannic acid equivalen-TAE) untuk senyawa tanin total dengan kurva standar, $\mathrm{y}=7.441 \mathrm{x}+0.033, \mathrm{r}^{2}=0,991$. Nilai ketiganya untuk tiap ekstraktan adalah: ekstrak etil asetat $85 \%$, sebesar $10,77 \pm 0,28 \%$ (g GAE/100 g EBD); 0,33 $\pm 0,001 \%$ (g QE/100 g-EBD) dan $6,32 \pm 0,26 \%$ (g TAE/100 g-EBD). Untuk ekstraktan etanol $50 \%$ beturut-turut $42,39 \pm 0,17 \%$ (g-GAE $/ 100$ g-EBD); 2,28 $\pm 0,06 \%$ (gQE/100 g-EBD) dan 22,21 $\pm 0,1 \%$ (g-TAE/100 g-EBD). Sedangkan untuk ekstraktan methanol $50 \%, 45,99 \pm 0,25 \%$ (g-GAE/100 g-EBD); $2,28 \pm 0,07 \%$ (g-

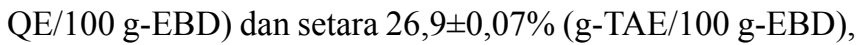
terlihat pada Gambar 1.

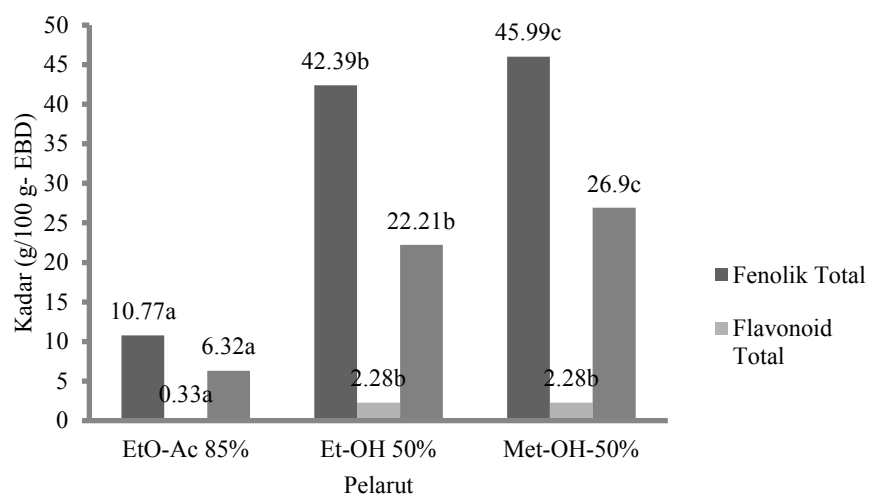

Gambar 1. Kelompok senyawa polifenolik EBD dari tiga ekstraktan berbeda. Huruf yang berbeda pada kolom kelompok senyawa polifenolik yang sama menunjukkan ada perbedaan nyata $(\mathrm{p}<0,05)$
Kadar kelompok senyawa polifenolik ekstrak dari ketiga jenis ekstraktan tersebut menunjukkan adanya perbedaan nyata $(P<0.05)$ antar perlakuan atas uji fenolik total, tanin total dan flavonoid total, kecuali antara pelarut etanol $50 \%$ dengan metanol $50 \%$ atas uji total flavonoid. Berdasarkan hasil tersebut terbukti, bahwa biji duwet merupakan sumber senyawa polifenolik (fenolik), seperti dikatakan para peneliti sebelumnya (Vasi dan Austin, 2009; Peixoto dan Freitas, 2012; Saha dkk., 2013).

Hasil tersebut jauh lebih tinggi dibanding yang dilaporkan Vasi dan Austin (2009). Dikemukakan ekstrak biji duwet bebas pelarut Et-OH50\% terkomposisi oleh senyawa fenolik setara 2,74 $\pm 0,02 \mathrm{~g}$-GAE/100 g-ekstrak dan flavonoid,

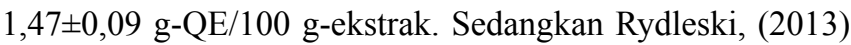
melaporkan ekstrak biji duwet bebas pelarut metanol mengandung senyawa fenolik setara 411,02 mg GAE/L dan 61,68 mg QE/L. Adapun Saha, dkk. (2013) menyatakan kandungan tanin biji duwet $21.000 \mathrm{mg}$ TAE/kg (ppm) dibanding $43.816 \mathrm{mg}$ TAE $/ \mathrm{kg}$ (ppm) yang setara dengan $26,90 \%$ (g-TAE/100 g-EBD). Hal ini dimungkinkan karena perbedaan varietas, lokasi tumbuh dan tingkat kemasakan buah (Vasi dan Austin, 2009; Vayupharp dan Laksanalamai, 2012).

Ekstrak etanol 50\% biji duwet, bila dikomparasikan dengan ekstrak etanol 50\% biji anggur (grape seed), dengan rasio bahan : pelarut $(10: 1)$ lama maserasi 6 jam suhu $50^{\circ} \mathrm{C}$, maka hasilnya comparable, yakni diperoleh yield $14,86 \pm 0,03 \%$, dan 32,86 $\pm 0,04$ g GAE/100 g-GSE (Vayupharp dan Laksanalamai, 2012). Jayaprakasha dkk. (2001) mengatakan ekstraksi senyawa fenolik biji anggur, dengan ekstraktan Met-OH memberikan yield tertinggi $(8,1 \pm 0,14 \%)$ dibanding acetone, etil acetat (EtO-Ac), tetapi jauh lebih rendah fraksi flavonoid total dibanding pelarut EtO-Ac dan kombinasinya dengan air. Ditambahkan flavonoid total

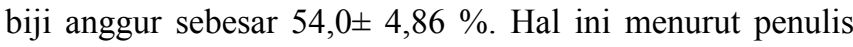
berpengaruh atas sifat antioksidatifnya. 


\section{Aktivitas Penangkapan Radikal DPPH}

DPPH adalah senyawa radikal bebas dan reaktif berwana violet dan memiliki absorbansi maksimal pada $\lambda=$ 515-528 nm. Intersitas warna akan mengecil (memudar) menjadi kuning seiring dengan transfer proton dari pendonor atom hidrogen utamanya senyawa fenolik. Semakin meningkat proses hidroksilasi (hydrogen atom transfer), maka dikatakan aktivitas penangkapan radikal DPPH (DPPH radical scavenging activity) oleh senyawa dimaksud makin kuat (Sultana dkk. 2007; Vasi dan Austin, 2009; Dai dan Mumper, 2010).

Dari ketiga EBD dengan ekstraktan EtO-Ac85\%, Et-OH50\%, dan Met-OH50\% serta dikomparasi dengan antioksidan BHA dan kuercetin, tampak bahwa ketiga EBD lebih besar aktivitas penangkapan radikal bebas DPPH dibanding BHA dan kuercetin, seperti ditunjukkan oleh Gambar 2. Aktivitas penangkapan radikal bebas DPPH dari ekstrak Met-OH 50\% paling kuat dan berbeda nyata $(\mathrm{p}<0,05)$ dibanding ekstrak lain dan BHA serta kuercetin, tetapi tidak berbeda nyata $(\mathrm{p}<0,05)$ dengan ekstrak Et-OH-50\% pada konsentrasi 100 ppm seperti terlihat pada Tabel 2.

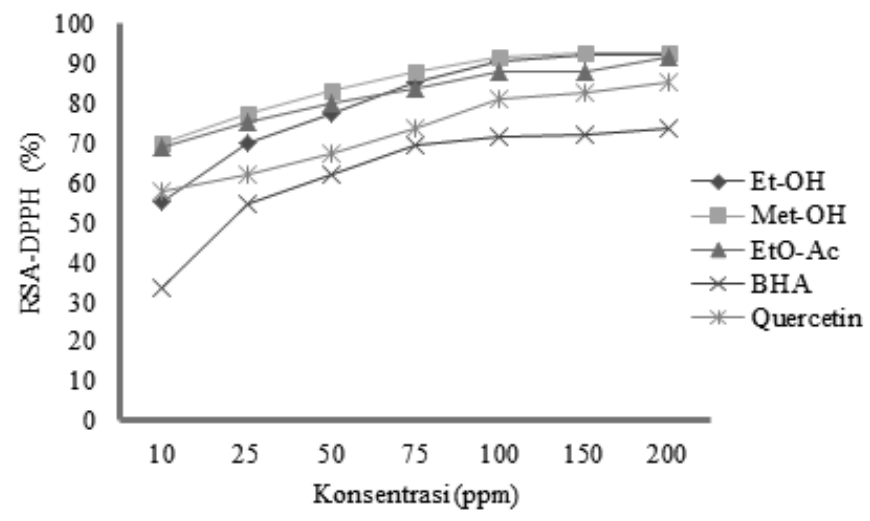

Gambar 2. Aktivitas penangkapan radikal bebas DPPH oleh ketiga EBD (Et-OH 50\%, Met-OH 50\% EtO-Ac 85\%), BHA dan quercetin

Hal demikian disebabkan kadar dan ragam kelompok senyawa polifenolik (fenolik) pada ekstrak Met-OH50\% lebih besar dibandingkan dua ekstrak lainnya dan lebih beragam, sementara BHA dan kuercetin adalah senyawa tunggal. Dari Gambar 2 diketahui nilai koefisien korelatif ( $r$ ), tiap-tiap EBD atas uji RSA-DPPH adalah sebagai berikut: Et-OH 50\% $(\mathrm{r}=0,904)$, Me-OH 50\% $(\mathrm{r}=0,86)$, EtO-Ac 85\% $(\mathrm{r}=0,91)$ dan quercetin $(\mathrm{r}=0,94)$ serta BHA $(\mathrm{r}=0,83)$.

\section{Aktivitas Mereduksi ion Feri $\left(\mathrm{Fe}^{3+}\right)$}

Kemampuan mereduksi ion Feri $\left(\mathrm{Fe}^{3+}\right)$ menjadi Fero $\left(\mathrm{Fe}^{2+}\right)$ oleh senyawa organik korelatif dengan kapasitas antioksidannya (Jayaprakasha dkk., 2001). Tabel 2, memperlihatkan hasil uji reduksi ion Feri (ferric reducing power-FRAP) dari tiga jenis ekstrak (EtO-AC85\%; Et$\mathrm{OH} 50 \%$ dan Met-OH50\%) pada konsentrasi $400 \mu \mathrm{g} / \mathrm{mL}$ berdasarkan metode reduksi potasiumferisianida $\left(\mathrm{K}_{3} \mathrm{Fe}(\mathrm{CN})_{6}\right)$ yang nilai absorbansinya (OD) 2.97, 2.82 dan 2.84. Tidak ada perbedaan yang nyata $(\mathrm{p}<0,05)$ nilai OD ketiganya dan juga dengan vitaman $\mathrm{C}$. Artinya baik ketiga ekstrak dan vitamin $\mathrm{C}$ memiliki kemampuan mereduksi setara hingga konsentrasi $400 \mu \mathrm{g} / \mathrm{mL}$. Jika konsentrasi ekstrak dinaikkan (1000 $\mu \mathrm{g} /$ $\mathrm{mL}$ ), tampak ketiga ekstrak menunjukkan peningkatan nilai OD hingga 3,2, namun tidak untuk vitamin $\mathrm{C}$.

Kadar tanin pada ketiga ekstrak diduga kuat berkontribusi pada uji RSA-DPPH dan FRAP yang tinggi. Zhang dan Lin (2009) mengatakan tanin pada buah duwet memiliki sifat antioksidatif yang baik pada uji DPPH dan reduksi ion Feri (FRAP) dan berasosiasi dengan senyawa reduktor (Brewer, 2011). Gordon (1990) menjelaskan sifat antioksidatif reduktor (reductones) berdasarkan pada mekanisme pemutusan rantai radikal bebas (breaking of the free radical -chain) dengan cara mendonasikan atom hidrogen.Reduktor juga bereaksi dengan prekursor peroksida, sehingga secara tidaklangsung mencegah formasi pembentukan peroksida. Data-data dari penelitian ini mengindikasikan bahwa sifat antioksidatif EBD dihasilkan dari sifat penangkapan radikal bebas dan kekuatan pereduksi. Hal ini sejalan dengan pendapat Zhang dan Lin (2009) bahwa sifat antioksidatif yang kuat buah duwet (whole fruit) disebabkan oleh kandungan tanin yang tinggi.

\section{Peroksidasi Asam Lemak Linoleat}

Sifat antioksidatif EBD, kuersetin dan BHA pada konsentrasi 400 ppm ditentukan melalui lipoksidasi emulsi asam lemak linoleat sesuai metode Jayaprakasha dkk. (2001) yang dipresentasikan pada Gambar 3. Dari gambar tersebut tampak bahwa ketiga EBD menunjukkan daya hambat peroksidasi berkisar 49-52 persen dibanding kontrol. Nilai tersebut setara dengan penghambatan antioksidan sintetik BHA dan lebih kuat dibanding kuersetin (47,7\%).

Radikal asam lemak linoleat $(\mathrm{R} \bullet$ ) yang terbentuk sebagai akibat abstraksi atom $\mathrm{H}$ dari salah satu diallylic methylen group, mudah teroksidasi membentuk radikal peroksida (ROO). Mekanisme antioksidan EBD pada penghambatan peroksidasi lipid adalah dengan cara mencegah dan atau menghambat peroksidasi asam lemak linoleat dengan monitoring pembentukan senyawa feri-thyocianat kompleks sebagai produk sekunder dekomposisi hidroperoksida yang diukur secara spektrometri absorbansinya pada $\lambda=500 \mathrm{~nm}$ (Hua- Ming, dkk., 1996; Jayaprakasha dkk., 2001).

Setelah inkubasi 96 jam, tampak nilai penghambatan semua ekstrak menurun, dan formasi pembentukan peroksida terhenti. Hal ini disebabkan sudah tidak tersedia substrat 


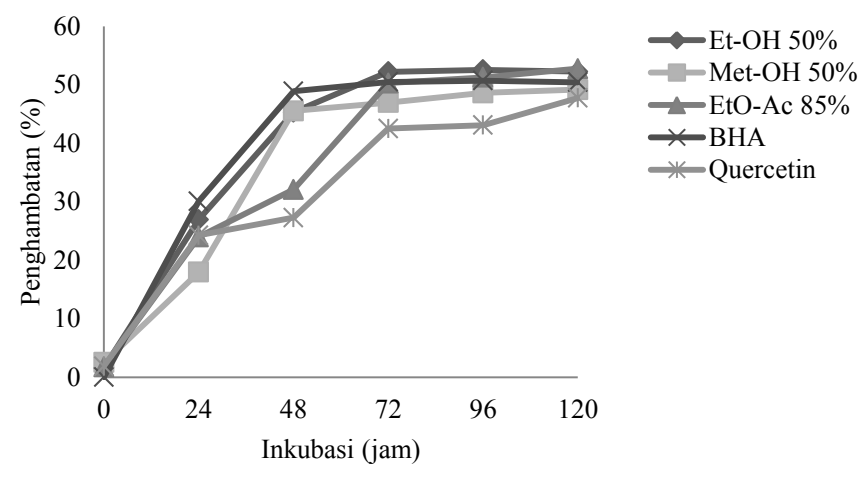

Gambar 3. Nilai penghambatan (\%) EBD (Et-OH 50\%, Met-OH $50 \%$, EtO-Ac 85\%), BHA dan Quercetin pada peroksidasi asam linoleat 400 ppm selama inkubasi 120 jam

(asam lemak linoleat) juga dimungkinkan karena produk intermediet terkonversi menjadi produk akhir yang stabil. Tidak tersedianya hidroperoksida sekaligus berakhirnya oksidasi fero sulfat menjadi feri sulfat dan feri-thiocianat kompleks (Jayaprakasha dkk., 2001).

Ekstrak etil acetat $85 \%$, etanol 50\% dan metanol $50 \%$ biji duwet, bilamana dikomparasikan dengan aktivitas penghambatan peroksidasi lipid pada ekstrak kulit pohon duwet (bark) bebas etanol 80\% dan methanol 80\% senilai 80-90\% (Sultana dkk., 2007), maka data-data pada Tabel 2 tampak lebih rendah. Demikian juga bila dikomparasikan dengan penghambatan oksidasi lipid oleh ekstrak biji anggur yang nilainya mencapai 86\% (Jayaprakasha dkk., 2001). Hal ini diduga disebabkan perbedaan komposisi dan jumlah senyawa fenoliknya. Disebutkan Jayaprakasha dkk. (2001) nilai flavonoid total pada ekstrak biji anggur (Vitis vinivera) bebas pelarut etil asetat sebesar $54,0 \pm 4,86 \%$.

\section{KESIMPULAN}

Dari penelitian ini terbukti bahwa biji duwet (Syzygium cumini Linn.) sumber senyawa polifenolik yang bersifat antioksidan. Sifat antioksidatif EBD adalah kuat pada uji penangkapan radikal bebas DPPH (radical scavenging activity-DPPH) dan pereduksi ion Feri $\left(\mathrm{Fe}^{3+}\right)$. Dari ekstrak Met-OH 50\% diperoleh yield terbesar 16,29\% (db.) dan kelompok fenoliknya adalah 45,99 $\pm 0,25 \%$ fenolik total (g-GAE/100 g-EBD); 2,28 $\pm 0,07 \%$ flavonoid total (g-QE/100 g-EBD) dan $26,9 \pm 0,07 \%$ tannin total (g-TAE/100g-EBD).

\section{UCAPAN TERIMA KASIH}

Penulis mengucapkan terima kasih kepada Kopertis Wilayah VI Semarang yang telah memfasilitasi penelitian ini dengan Hibah Penelitian 2015 Batch 1 melalui skema
Penelitian Disertasi Doktor dari Kementerian Ristek dan Pendidikan Tinggi.

\section{DAFTAR PUSTAKA}

Ali, E.M., Feresteh, P. dan Hafezi, S. (2008). Antioxidan activities of Iranian corn silk. Turkish Journal of Biology 32: 43-49.

AOAC (2005). AOAC Official Methods of Analysis. $18^{\text {th }}$ ed. AOAC Intern. Maryland, USA.

Ayyanar, M. dan Babu, P.S. (2012). Syzygium cumini (L.): A review of its phytochemical constituents and traditional uses. Asian Pacific Journal of Tropical Biomedicine 2(3): 240-246.

Baliga, M.S., Baht, H.P., Baliga, B.R.V., Wilson, R. dan Palatty, P.L. (2011). Phytochemistry, tradisional uses and pharmacology of Eugenia jambolana Lam. (black plum): A review. Food Research International 44: 1776-1789.

Baydar, N.G., Ozkan, G. dan Yasar, S. (2007). Evaluation of the antiradical and antioxidant potential of grape extract. Food Control 18: 1131-1136.

Brewer, M.S. (2011). Natural antioxidant: source, compounds, mechanisms of action, and potential application. Comprehensive Reviews. Food Science and Food Safety 10: 221-247.

Buxiang, S. dan Fukuhara, M. (1997). Effect of coadministration of butylated hydroxytoluene, butylated hydroxyanisole and flavonoids on the activation of mutagens and drugs-metabolizing enzymes in mice. Toxicology 122(2-4): 61-72.

Dai, J. dan Mumper, R.J. (2010). Plant phenolics: extraction, analysis and their antioxidant and anticancer properties (review). Molecules 15: 7313-7352.

Faria, A.F., Marques, M.C. dan Mercadante, A.Z. (2011). Identification of bioactive compounds from jambolao (Syzygium cumini) and antioxidant capacity evaluation in different pH conditions. Food Chemistry 126: 15711579.

Gordon, M.F. (1990). The mechanism of antioxidant action in vitro. Dalam: J.F. Hudson (ed.). Food Antioxidant, hal: 1-18. Elsevier Applied Science, London.

Jayaprakasha, G.K., Singh, R.P. dan Sakariah, K.K. (2001). Antioxidant activity of grape seed (Vitis vinifera) extracts on peroxidation models in vitro. Food Chemistry 73: 285-290. 
Madavi, D.L. dan Salunkhe, D.K. (1995). Toxicological aspect of food antioxidant. Dalam: Madavi, D.L., Despandhe, S.S. dan Salunkhe, D.K. (ed.). Food Antioxidant. Mercel Decker Inc., NY.

Maqsood, S. (2010). Maximized Uses of Phenolic Compound in Retardation of Lipid Oxidation and Shelf-Life Extension of Fish and Fish Product. A thesis submitted in Fulfillment of the Requirements of Degree of Doctor of Philosophy in Food Science and Technology Prince of Songkla University.

Palici, I., Tita, B., Ursica, L. dan Tita, D. (2005). Method for quantitative determination of polyphenolic compounds and tannins from vegetal Products. Acta Universitatis Cibiniensis Seria F. Chemia 8: 21-32.

Peixoto, Paula, M.G. dan Freitas, L.A.P. (2012). Spray-dried extracts from Syzygium cumini seed: physicochemical and biological evaluation. Brazilian Journal of Pharmacognosy 23(1): 145-152.

Rydlewski, Adriela, A., de Morais, D.R., Rotta, E.M. dan Visentainer, J.V. (2013). Evaluation of antioxidant activity of methanolic extract of seed, peel, and pulp of jambolan (Syzygium Cumini). Agricultural Science Center of State University of Marings, Colombo. http:// www.Iufos.org. [10 September 2013].

Saha, Repon, K., Zaman, N.M. dan Roy, P. (2013). Comparative evaluation of the medicinal activities of methanolic extract of seed, fruit pulp and fresh juice of Syzygium cumini in vitro. Journal of Coastal Medicine 1(4): 288-296.

Shahidi, F. dan Zhong, Y. (2005). Antioxidants: Regulatory Status. Bailey's Industrial Oil and Fats Products. $6^{\text {th }}$ ed. John Wiley and Sons Inc, Canada.

Sultana, B., Anwar, F. dan Przybylski, R. (2007). Antioxidant activity of phenolic components present in bark of Azadirachta indica, Terminalia arjuna, Acacia nilotica dan Eugenia jambolana Lam. trees. Food Chemistry 104: 1106-1114.

Swami, Shrikant, B., Thakor, N.S.J., Patil, M.M. dan Haldankar, P.M. (2012). Jamun (Syzygium cumini L.): A review of its food and medicinal uses. Food and Nutrition Science 3: (1100-1117).

Vayupharp, B. dan Laksanalamai, V. (2012). Recovery of antioxidant from grape seeds and its application in fried food. Journal of Food Processing Technology 3(4): 1-6.

Vasi, S. dan Austin, A. (2009). Antioksidan potential of Eugenia jambolana Lam. seeds. Journal of Biological Sciences 9(8): 894-898.

Zhang, L.L. dan Lin, Y.M. (2009). Antioxidant tannins from Syzygium cumini fruit. African Journal of Biotechnology 8(10): 2301-2309. 